\title{
Bacteriology in Patients With Chronic rhinosinusitis in North of Iran(Sari)
}

\author{
Seyyed Abdollah Madani ${ }^{1}$, Seyyed Abbas Hashemi ${ }^{2,}$, , Mehran Fazli ${ }^{2}$, Kiomars Esfandiar ${ }^{1}$ \\ ${ }^{1}$ Department of Otorhinolaryngology, Head and Neck Surgery, Traditional and Complementary Medicine Research Center, Mazandaran University of Medical Sciences, Sari, IR Iran \\ 2 Faculty of Medicine, Student Research Committee, Mazandaran University of Medical Sciences, Sari, IR Iran \\ ${ }^{*}$ Corresponding author: Seyyed Abbas Hashemi, Department of Otorhinolaryngology, Head and Neck Surgery, Traditional and Complementary Medicine Research Center, Mazanda- \\ ran University of Medical Sciences, Sari, IR Iran, Tel.: +98-9112581083, Fax:+98-1513244893, E-mail: abbas.hashemi30@gmail.com.
}

Received: September 24, 2012; Revised: October 30, 2012; Accepted: December 15, 2012

\begin{abstract}
Background: Chronic rhinosinusitis is an inflammatory-infectious disease involved paranasal sinuses as a common site of microbial pathogens and infections in patients suffering from the disease. The disease is labeled chronic when it lasts for more than 12 weeks.

Objectives: As these infections constitute an important cause of morbidity it can be a strong life-threatening factor, in this investigation we examine the bacterial strains involved in development of chronic rhinosinusitis.

Materials and Methods: This research was a prospective study of the bacterial strains involved in development of chronic rhinosinusitis in patients referred to Bou-Ali Sina Hospital in Sari, Iran. The study population included 253 patients with chronic rhinosinusitis. Samples were collected from all patients' nasal discharge, which were cultured to investigate the type of microbial infection. The staining methods were Gram staining, Chinese ink staining, acid-fast staining and Papanicolaou staining. Finally, specific tests for detection and differentiation of the strains were performed.

Results: Out of 253 patients, 124 (49.1\%) were adult male, 49 (19/36\%) were adult female and 80 patients (31.62\%) were children under 5 years. The most common clinical symptoms including post-nasal drip (40.47\%) and headache (32.62\%). In general, the most isolated bacteria were Staphylococcus aureus (37.1\%) and Pneumococcus (23.53\%).

Conclusions: In this study, it was found that S. aureus and Pneumococcus contributed the most to development of chronic rhinosinusitis.
\end{abstract}

Keywords: Chronic rhinosinusitis; Bacteriology;

\section{Background}

Chronic rhinosinusitis is an inflammatory-infectious disease that can affect frontal, sphenoid, ethmoid, and maxillary sinuses. The disease is called chronic if the disease persists for more than three months from its onset $(1,2)$. The global prevalence of rhinosinusitis has been estimated between $14 \%$ and $15 \%$ in various communities, which makes it one of the most prevalent chronic diseases in the world $(3,4)$. Moreover, owing to its accompanying complications, the disease is considered to be among the ten most debilitating diseases (5). Some symptoms of rhinosinusitis are: a feeling of fullness in the face, nasal congestion and obstruction, post-nasal drip, erythema and edema of forehead or cheeks, olfactory disorder, cough, and edema and hyperemia of nasal mucosa (6). Several factors contributed to the disease, ranging from environmental factors to genetic ones (7), among which the acute rhinosinusitis that has not been completely cured is more likely to turn to the chronic form (8). Different complications have been reported for the disease, including orbital cellulitis, periosteal abscess, osteomyelitis, intracranial complications, and cavernous sinus thrombosis (9). The standard diagnostic method for rhi- nosinusitis is CT-scan. However, in order to find the underlying causes of the disease and determine the feasible antibiotic, it is always necessary to perform bacterial culture and determine the pathogens (10).

The important bacterial pathogens in acute rhinosinusitis are Streptococcus. pneumoniae, Haemophilus influenzae, and Moraxella catarrhalis, whereas anaerobic bacteria and Staphylococcus aureus are considerable in chronic rhinosinusitis.

\section{Objectives}

The direct and indirect virulent characteristics of these bacteria need the prescription of suitable antimicrobial therapy directed against all microorganisms in mixed infections (11). Considering the importance of this issue, we have studied the bacterial strains involved in development of chronic rhinosinusitis.

\section{Patients and Methods}

This is a prospective study, which was carried out in two years on patients with chronic rhinosinusitis who were referred to the Bu-Ali Sina Hospital, in Sari, Iran. We included 253 patients. Culture samples were obtained by

Implication for health policy/practice/research/medical education:

It was found that S. aureus and Pneumococcus contributed the most to development of chronic rhinosinusitis that can provide evidences about suitable antibiotic therapy.

Copyright @ 2013, Ahvaz JundishapurUniversity of Medical Sciences; Published by Kowsar Corp. This is an open-access article distributed under the terms of the Creative Commons Attribution License, which permits unrestricted use, distribution, and reproduction in any medium, provided the original work is properly cited. 
sampling from nasal and pharyngeal discharges, sinus puncture, sinus orifice samples taken by a swab, and the samples obtained during surgical operations. We prepared smears from the samples and then stained them for primary evaluations.

The staining methods used in this study were Gram staining to study bacterial morphology, Chinese ink staining to detect the capsulated bacteria, acid-fast staining, and Papanicolaou staining. Then, the samples were cultured on agar (Merck, Germany), chocolate agar (Merck, Germany), under 10 - 15\% CO2 pressure, Mac Conkey (Merck, Germany), and eosin methylene blue media (Merck, Germany). The culture media were incubated at $37^{\circ} \mathrm{C}$ for 24 hours, and after emergence of the colonies, the primary differential diagnosis tests were performed on the colonies. Then, specific tests for detection and differentiation of the strains were performed.

\section{Results}

The study was performed on 253 patients, among whom 124 patients (49.01\%) were male, 129 patients $(50.98 \%)$ were female. 80 patients (31.62\%) in this study were children under 5 years old.

\begin{tabular}{ll}
\hline \multicolumn{2}{l}{ Table 1. Frequency of Clinical Symptoms Among the Patients } \\
\hline \multicolumn{1}{l}{ Clinical Symptom } & Frequency, \% \\
\hline Extreme post-nasal drip & 40.03 \\
\hline Headache particularly in the forehead & 32.62 \\
\hline $\begin{array}{l}\text { Nasal obstruction } \\
\text { Respiratory problems and snoring }\end{array}$ & 9.77 \\
$\begin{array}{l}\text { Local pain on sinuses and peri-orbital } \\
\text { region }\end{array}$ & 5.03 \\
\hline \begin{tabular}{l} 
Frequent common cold \\
\hline
\end{tabular} & 5.07 \\
\hline
\end{tabular}

Table 2. Frequency of Microorganisms Isolated From Pharyngeal Samples

\begin{tabular}{lll}
\hline Microorganism & Strain & No.\% \\
\hline Neisseria & 147 & 26.48 \\
\hline Pneumococcus & 140 & 25.22 \\
\hline Staphylococcus aureus & 131 & 23.6 \\
\hline Alpha-hemolytic streptococci & 102 & 18.37 \\
\hline Beta-hemolytic streptococci & 22 & 3.96 \\
\hline Klebsiellaozaenae & 7 & 1.26 \\
\hline Diphtheroid & 2 & 0.36 \\
\hline Pseudomonas & 2 & 0.36 \\
\hline Citrobacter & 1 & 0.18 \\
\hline Haemophilusparainfluenzae & 1 & 0.18 \\
\hline
\end{tabular}

The clinical symptoms of the patients according to their prevalence were extreme post-nasal drip (40.03\%), headache particularly in the forehead (32.62\%), nasal congestion $(9.77 \%)$, respiratory problem and snoring (7.03\%), local pain on sinuses and peri-orbital region (5.47\%), and frequent common cold (5.07\%) (Table 1).

From the samples, 830 bacterial strains were isolated, among which 555 (66.86\%) and 275 (33.13\%) strains were isolated from pharyngeal and nasal discharges, respectively. The most frequently isolated strain from pharyngeal samples was Neisseria (26.48\%) and the least frequently isolated strains were $H$. parainfluenzae $(0.18 \%)$ and Citrobacter $(0.18 \%)$, respectively (Table 2$)$. With regard to the bacteria isolated from nasal samples, S. aureus (64.36\%) and $H$. parainfluenzae were the most and the least frequently isolated strains, respectively (Table 3).

Table 3. Incidence of Microorganisms Isolated From Nasal Samples

\begin{tabular}{lll}
\hline Microorganism & Strain & No.\% \\
\hline Staphylococcus aureus & 177 & 64.36 \\
\hline Pneumococcus & 49 & 17.81 \\
\hline Neisseria & 33 & 12 \\
\hline Alpha-hemolytic streptococci & 8 & 2.9 \\
\hline Klebsiellaozaenae & 4 & 1.45 \\
\hline Diphtheroid & 3 & 1.09 \\
\hline Citrobacter & 1 & 0.36 \\
\hline Beta-hemolytic streptococci & - & - \\
\hline Pseudomonas & - & - \\
\hline Haemophilusparainfluenzae & - & - \\
\hline
\end{tabular}

Table 4. The Frequency of Microorganisms Isolated From the Nasal and Pharyngeal Samples in both genders.

\begin{tabular}{|c|c|c|}
\hline Microorganism & $\begin{array}{l}\text { Frequency in } \\
\text { Men, No. (\%) }\end{array}$ & $\begin{array}{l}\text { Frequency in } \\
\text { Women, No. (\%) }\end{array}$ \\
\hline Staphylococcus aureus & $103(47.68)$ & $113(52.31)$ \\
\hline Pneumococcus & $72(46.15)$ & $84(53.84)$ \\
\hline $\begin{array}{l}\text { NeisseriaandBranha- } \\
\text { mella }\end{array}$ & $80(50.31)$ & $79(49.68)$ \\
\hline $\begin{array}{l}\text { Alpha-hemolytic strep- } \\
\text { tococci }\end{array}$ & $49(44.54)$ & $61(55.45)$ \\
\hline $\begin{array}{l}\text { Beta-hemolytic strepto- } \\
\text { cocci }\end{array}$ & $11(50)$ & $11(50)$ \\
\hline Klebsiellaozaenae & $5(45.45)$ & $6(54.54)$ \\
\hline Diphtheroid & $1(20)$ & $4(80)$ \\
\hline Citrobacter & $1(50)$ & $1(50)$ \\
\hline Pseudomonas & $2(100)$ & - \\
\hline $\begin{array}{l}\text { Haemophilusparainflu- } \\
\text { enzae }\end{array}$ & $1(100)$ & - \\
\hline
\end{tabular}


Considering the frequency of different strains in male and female patients, bacteria such as S. aureus, Pneumococcus, alpha-hemolytic Streptococci, Klebsiella, and Diphtheroid were more common among female patients. while the infection frequency with beta-hemolytic Streptococci, Neisseria , and Branhamella were similar in male and female patients (Table 4). In general, the most and the least frequent bacteria isolated from the patients were S. aureus (37.1\%) and $H$. parainfluenzae (0.12\%), respectively (Table 5).

Table 5. Frequency of Microorganisms Isolated From the Patients' Nasal and Pharyngeal Samples

\begin{tabular}{ll}
\hline Microorganism & No.\% \\
\hline Staphylococcus aureus & 37.1 \\
\hline Pneumococcus & 23.53 \\
\hline Neisseria & 21.68 \\
\hline Alpha-hemolytic streptococci & 13.25 \\
\hline Beta-hemolytic streptococci & 2.65 \\
\hline Klebsiellaozaenae & 1.35 \\
\hline Diphtheroid & 0.6 \\
\hline Citrobacter & 0.25 \\
\hline Pseudomonas & 0.25 \\
\hline Haemophilusparainfluenzae & 0.12 \\
\hline
\end{tabular}

\section{Discussion}

Chronic rhinosinusitis is an inflammatory-infectious disease involving the nose and its surrounding sinuses. The condition is called chronic when it lasts more than 12 weeks from its onset (12). The disease affects more than $15 \%$ of the population (13). In our study, the most frequently observed symptoms were extreme post-nasal drip, headache particularly in the forehead, and nasal obstruction. This is similar to the results reported by Fokkens et al. They reported nasal congestion, post-nasal drip, facial pain or fullness, and reduced olfactory sensation as major symptoms of the disease (14).

In our study, the most frequent isolated bacteria were S. aureus, followed by Pneumococcus and Neisseria. Moreover, the least frequent strains were $H$. parainfluenzae, Pseudomonas, and Citrobacter. Our results had some dissimilarities with those reported by Mantovani et al. In their study, the commonest bacterium was Gram-negative; Pseudomonas aeruginosa (27.6\%), followed by two Gram-positive bacteria; S. aureus and S. epidermis (15).

The difference could probably be explained by their smaller sample size (62 patients) and limited sampling scope, samples only obtained from the maxillary sinus. In another study, Busaba et al. evaluated the microbiology of chronic ethmoidal sinusitis in 263 patients. They reported that coagulase-negative Staphylococcus (51\%) was the commonest bacterium isolated from the patients, followed by S. aureus (18\%) (16). This is while S. aureus was the most frequent microorganism isolated in the current study. Yildirim et al. (17) collected samples from 48 patients who underwent medical treatment at least for three months, and were candidate for surgery since they did not respond to the treatment. In their investigation, the most frequent microorganisms isolated were coagulase-negative Staphylococcus (45.8\%), and then S. pneumonia (16.7\%), Enterobacteriaceae (16.7\%), S. aureus (10.4\%), and P. aeruginosa (10.4\%).

Torabi et al. studied 88 patients with chronic rhinosinusitis who were resistant to the medical treatment. They obtained samples using endoscopic methods. In their study, the commonest strains were coagulase-negative Staphylococcus (29.5\%), S. aureus (19.1\%), and Klebsiella (14.1\%) (6). In most studies, coagulase-negative Staphylococcus has been reported as the most frequent strain, followed by S. aureus. This is while in our study, S. aureus and then Pneumococcus were the most frequently isolated strains. The difference between the results could be probably attributed to the differences in sampling method and the studied populations.

\section{Acknowledgements}

The authors wish to thank all those who kindly cooperated in fulfillment of the research project.

\section{Authors' Contribution}

None declared.

\section{Financial Disclosure}

There is no Financial Disclosure.

\section{Funding/Support}

There is no Funding/Support.

\section{References}

1. Maning SC. Medical management of inf. \& inflammatory Dis. 3 ed. Cummings C.W Fredrikson JM, Otolaryngol, Head \& Neck sur. 1998.

2. Pinheiro AD, Facer GW, Kern E. Rhinosinusitis. 3 ed. Bailey.B.J; head \& Neck sur Otolaryngol .: philadelphia. Williams \& Wilkins; 2001

3. Anand Vijay K, Osguthorpe JDavid, Rice Dale. Surgical Management of Adult Rhinosinusitis. Otolaryngology -- Head and Neck Surgery. 1997;117(3 suppl):S50-S52.

4. Chen Y, Dales R, Lin M. The epidemiology of chronic rhinosinusitis in Canadians. Laryngoscope. 2003;113(7):1199-205.

5. Goetzel RZ, Hawkins K, Ozminkowski RJ, Wang S. The health and productivity cost burden of the "top 10" physical and mental health conditions affecting six large U.S. employers in 1999. J Occup Environ Med. 2003;45(1):5-14.

6. Torabi MA, Hashemi SM, Abtahi SM, Soheilipour S, Fazeli A Shadzi S. , et al. Frequency of common strains of chronic sinusitis in adults and classification of their antibiotic susceptibility and resistance. J Med Council Islam Rep Iran. 2007;26(3):337-345.

7. Takeuchi K, Majima Y, Shimizu T, Ukai K, Sakakura Y. Analysis of HLA antigens in Japanese patients with chronic sinusitis. Laryngoscope. 1999;109(2 Pt 1):275-8.

8. Biel MA, Brown CA, Levinson RM, Garvis GE, Paisner HM, Sigel ME, 
et al. Evaluation of the microbiology of chronic maxillary sinusitis. Ann Otol Rhinol Laryngol. 1998;107(11 Pt 1):942-5.

9. Sother AD. Curent Concept As Management. 2 ed: Philadelphia.Raven Press; 1998.

10. Slavin RG, Spector SL, Bernstein IL, Kaliner MA, Kennedy DW Virant FS, et al. The diagnosis and management of sinusitis: a practice parameter update. J Allergy Clin Immunol. 2005;116(6 Suppl):S13-47.

11. Brook I. Microbiology and antimicrobial management of sinusitis.J Laryngol Otol. 2005;119(4):251-8.

12. Lund VJ. Impact of chronic rhinosinusitis on quality of life and health care expenditure. Clin Allergy Immunol. 2007;20:15-24.

13. Fokkens W, Lund V, Mullol J, European Position Paper on Rhinosinusitis, Nasal Polyps group. Rhinol Suppl. 2007(20):1-136.
14. Fokkens WJ, Lund VJ, Mullol J, Bachert C, Alobid I, Baroody F, et al. EPOS 2012: European position paper on rhinosinusitis and nasal polyps 2012. A summary for otorhinolaryngologists. Rhinology. 2012;50(1):1-12.

15. Mantovani K, Bisanha AA, Demarco RC, Tamashiro E, Martinez $\mathrm{R}$, Anselmo-Lima WT. Maxillary sinuses microbiology from patients with chronic rhinosinusitis. Braz J Otorhinolaryngol. 2010;76(5):548-51.

16. Busaba NY, Siegel NS, Salman SD. Microbiology of chronic ethmoid sinusitis: is this a bacterial disease? Am J Otolaryngol. 2004;25(6):379-84.

17. Yildirim A, Oh C, Erdem H, Kunt T. Bacteriology in patients with chronic sinusitis who have been medically and surgically treated. Ear Nose Throat J. 2004;83(12):836-8. 